NBER WORKING PAPER SERIES

\title{
LIQUIDITY INSURANCE IN A FINANCIALLY DOLLARIZED ECONOMY
}

Eduardo Levy Yeyati

Working Paper 12345

http://www.nber.org/papers/w12345

\author{
NATIONAL BUREAU OF ECONOMIC RESEARCH \\ 1050 Massachusetts Avenue \\ Cambridge, MA 02138 \\ June 2006
}

The author wishes to thank Marco Bonomo, Alejandro Werner and participants at the December 2005 NBER Inter-American Seminar on Economics in Rio de Janeiro for their helpful comments, and Ramiro Blázquez and Luis Casanovas for their outstanding research assistance. The paper is forthcoming in Strengthening Global Financial Markets, (Sebastian Edwards and Marcio Garcia, eds.,), University of Chicago Press. The views expressed herein are those of the author(s) and do not necessarily reflect the views of the National Bureau of Economic Research.

(C2006 by Eduardo Levy Yeyati. All rights reserved. Short sections of text, not to exceed two paragraphs, may be quoted without explicit permission provided that full credit, including $(\subset)$ notice, is given to the source. 
Liquidity Insurance in a Financially Dollarized Economy

Eduardo Levy Yeyati

NBER Working Paper No. 12345

June 2006

JEL No. G2, F3

\begin{abstract}
$\underline{\text { ABSTRACT }}$
Unlike the financial dollarization (FD) of external liabilities, the dollarization of domestic financial assets (domestic FD) has received comparatively less attention until very recently, when it has been increasingly seen as a key source of balance sheet exposure. This paper focuses on a complementary -and often overlooked-angle of domestic FD: the limit it imposes on the central bank as domestic lender of last resort, and the resulting exposure to dollar liquidity runs. The paper discusses the incidence of FD on banking crisis propensity, shows that FD has been an important motive for self insurance in the form of international reserves, and highlights the moral hazard associated with centralized reserve accumulation. Next, it illustrates the authorities' belated recourse to suspension of convertibility in two recent banking crises (Argentina 2001 and Uruguay 2002). Finally, it argues for a combined scheme of decentralized reserves (liquid asset requirements on individual banks) to limit moral hazard, and an ex-ante suspension-of-convertibility clause ("circuit breakers") to reduce self-insurance costs while limiting bank losses in the event of a run.
\end{abstract}

Eduardo Levy Yeyati

Universidad Torcuato Di Tella

Miñones 2177

(1428) Buenos Aires

ARGENTINA

ely@utdt.edu 


\section{Introduction}

While the foreign-currency denomination (dollarization, for short) of external liabilities typical of most financially integrated developing economies has been the subject of a vast body of academic work, ${ }^{2}$ the dollarization of domestic financial assets has received comparatively less attention until very recently, when it has been increasingly seen as a key source of real exchange rate exposure and banking (and macroeconomic) fragility. ${ }^{3}$ There is, however, an angle of domestic financial dollarization (FD) that, while intuitive, has been somewhat overlooked: the limit it imposes on the central bank as domestic lender of last resort (LLR), and the resulting exposure to dollar liquidity runs à la Diamond and Dybvig (1983; DD). ${ }^{4}$ Thus, the growing literature on balance sheet effects and de-dollarization contrasts with the less developed literature on how to manage liquidity in the (potentially long) interim period when FD remains high. This is the subject of the present paper.

The analysis of dollar liquidity runs in FD economies has often centered on the economy as a whole, stressing the need for "insurance" mechanisms, and the limitations of the available options. ${ }^{5}$ While most of this debate also applies to the analysis of banking crises, there are some important specificities that the macroeconomic focus has tended to leave in the dark.

In particular, once one considers the banking sector as the object of insurance, a number of questions arise. Are the central bank's (centralized) and the individual banks' (decentralized) hoarding of reserves equivalent? How can the costs of self-insurance be

2 Examples include the literature on "original sin" (Eichengreen and Hausmann, 2005), "liability dollarization cum sudden stop" (Calvo, 2005), and "dollar shortages" (Caballero and Krishnamurty, 2002, Rajan, 2004).

${ }^{3}$ Domestic FD introduces a hidden short position in the foreign currency (either at the bank or at the debtor level) exposing the economy as a whole to sudden real exchange rate depreciations. See De Nicoló, Honohan, and Ize (2003), and Levy Yeyati (2006) for empirical analyses along these lines. Armas, Ize and Levy Yeyati (forthcoming) provide a compendium on this relatively new literature.

${ }^{4}$ By contrast, this issue has been often highlighted in the official dollarization debate (Broda and Levy Yeyati, 2003a).

5 Thus, Jeanne and Ranciere (2005) discuss the optimal level of self insurance through reserve accumulation, Aizenman and Lee (2005) show that reserve hoarding provides welfare gains, Caballero and Panageas (2004) propose the use of derivatives to maximize the insurance value of reserves, whereas Cordella and Levy Yeyati (2005a) argue in favor of external insurance, and Cordella and Levy Yeyati (2005b) stress the drawbacks of private external insurance and current IMF-led packages, and point to the convenience of ad hoc multilateral official agreements to reduce the costs of self-insurance. 
reduced in the absence of an external alternative? Can a suspension of convertibility clause (often applied ex post, too late, when the bank run is well underway) be used ex-ante to supplement self-insurance?

To address these questions, I proceed in four steps. First, I revisit the evidence on the incidence of FD on the propensity to suffer bank runs and document the positive link between FD and reserve accumulation. I show that FD has been a motive for this form of self insurance - in addition to the capital account reversal often noted in the literature.

Next, I analyze and compare available insurance options, and explore the incentive problems associated with centralized holdings of reserves at the central bank, when the latter, among other uses, are expected to provide dollar liquidity insurance to individual banks. In particular, I show that centralized reserves can deepen the moral hazard problem within the banking industry and induce further dollarization.

Then, I illustrate the authorities' decision to suspend convertibility in the context of a run with the story of two recent banking crises: Argentina 2001 and Uruguay 2002.

Finally, I argue in favor of a combined scheme of decentralized reserves (liquid asset requirement on individual banks or LAR) to limit moral hazard, and an ex-ante suspensionof-convertibility clause or "circuit breaker" (CBR) to mitigate the costs of belated action in the event of a run while limiting the need for costly self insurance. ${ }^{6}$

The logic behind this combination is simple. Exposure to runs is an inevitable consequence of a banking system that transforms short-run savings into long-run investments. In the absence of a LLR that can produce liquidity on demand, the bank supervisor faces two options to reduce this maturity mismatch: (i) liquid reserves, which reduce the average length of bank assets (in the limit, "narrow banking" eliminates both bank runs and bank financing), and (ii) CBRs, which increase the average length (reduce the effective liquidity) of bank deposits (in the limit, approaching illiquid corporate debt). If the opportunity cost of reserve hoarding (proportional to the marginal productivity of capital) increases with the volume of reserves, and the liquidity premium (proportional to the marginal utility of consumption) increases as the CBR gets more restrictive, the optimal solution is a combination of LAR and CBR. ${ }^{7}$

\footnotetext{
${ }^{6}$ See Ize, Kiguel and Levy Yeyati (2005), where this scheme was first outlined.

${ }^{7}$ In essence, this analysis moves a step back from DD's original argument. If dollar deposit insurance cannot be tax- or debt-financed on demand and needs to be funded in advance, the amount of
} 


\section{FD, bank runs and reserves}

Deposit dollarization it is not only the most amply documented aspect of de facto dollarization but also (and for the same reason) the subject of most of the early FD literature. ${ }^{8}$ Despite the recent focus on external (official and unofficial) debt, domestic FD remains a widespread, persistent and economically significant phenomenon, with distinct prudential implications. A quick look at the map of domestic FD confirms that it is not a localized phenomenon (Figure 1) and that is has been remarkably stable in recent years (Table 1). On the other hand, most recent systemic banking crises have taken place in domestically dollarized economies (Table 2), a link already highlighted in the literature. ${ }^{10}$

Not surprisingly, then, domestically dollarized economies have tended to "insure" themselves through the hoarding of liquid foreign assets, much in the same way as countries experiencing sudden capital account reversals have revealed a preference for a high stock of international reserves. In this particular case, reserves holdings can be centralized at the central bank or decentralized at individual banks (in the form of reserve money or liquid asset requirements). Table 3 reports the summary statistics for both types. In addition, it shows that they are highly correlated with the degree of deposit dollarization, and between themselves.

This first impression is confirmed by more rigorous empirical testing. Table 4 reports within and between estimates from panel regressions of different types of reserve holdings (including banks' holdings of foreign assets outside the central bank) on deposit

insured deposits (but not insurance coverage) is predetermined, and suspension of convertibility (too rigid relative to a deposit insurance à la DD) looks again as a viable second best alternative.

${ }^{8}$ By contrast, comprehensive data on the currency composition of sovereign debt can be found only for a limited group of middle- to high-income countries (see Cowan, Levy Yeyati, Panizza and Sturzenegger, 2006).

${ }^{9}$ De Nicoló et al. (2003) report that FD increases banks risk and deposit volatility, and Levy Yeyati (2006) shows that a devaluation raises the banking crisis propensity (only) in the presence of FD.

${ }^{10}$ Domestic FD in Figure 1 is computed as the ratio of onshore dollar deposits over total onshore dollar deposits. With the exception of FD, all ratios in the paper are normalized by GDP. It is important to note that FD refers to the use of a currency other than the domestic legal tender. Hence, the very low levels of FD in officially dollarized Panama, Ecuador, El Salvador. 
dollarization. ${ }^{11}$ All within regressions include a time trend to capture the noted trend towards reserve accumulation due to increased financial integration (irrespective of the degree of FD). All results convey the same message: deposit dollarization is strongly related with the holding of foreign assets, both across countries and dynamically for each country. (In passing, note also that there seems to be indeed a significant upward trend in reserve holdings).

Table 5, in turn, indicates that this association between FD and reserves applies primarily to economies where FD is economically important. Splitting the sample into two groups, according to whether average dollar deposit-to-GDP ratio for the country is below of above the sample mean (roughly 10\%), shows that link is strong and significant only for the latter. (Interestingly, this appears to be the case also for the time trend). Figure 5 further illustrates this point. The results are robust to the inclusion of a measure of financial depth: broad money over GDP ( $\left.m 2 \_g d p\right)$ to control for the fact that the accumulation of reserves may be simply reflecting financial development. While this prior seems to be right (financial depth does seem to be positively related with the stock of liquid reserves), the results concerning FD remain virtually unchanged. Finally, this specification may be too imprecise should the surge in reserve holding be attributed not to a steady trend but to a response to specific events in the recent past. ${ }^{12}$ For this reasons, in the last two columns I replace the time trend for individual year dummies. While these time effects seem to exhibit an upward trend in the recent period (coinciding but not necessarily due to the Mexican and Asian episodes, as shown in Figure 2), their inclusion has no visible effect on the coefficient of interest.

Table 6 presents several robustness checks. Columns (1) and (2) replicate the specification of Table 5, column (5), for the Latin American and non-industrial sub-samples, while columns (3) and (4) add the change in the nominal exchange rate (dler) to control for the mercantilist motivation for reserve hoarding, and the external debt ratio (ext_debt_gdp) to capture another source of dollar exposure often highlighted in the literature. With the exception of a slightly lower coefficient when debt is included (due to the smaller sample

${ }^{11}$ Bank foreign assets are included here for completeness. It should be noted, however, that should not be interpreted as reflection of self insurance, for at least two reasons. First, they are likely to reflect standard prudential limits on the banks' open foreign currency position. Second, they are likely to be longer, less liquid assets that offer returns above that paid by liquid reserves, and thus may simply be the reflection of the bank's portfolio choice.

12 For example, Aizenman and Lee test the hypothesis of precautionary reserves by regressing reserves holdings on a dummy that is equal to one in the years following the Asian an Mexican crises. 
size), the results are unaltered. ${ }^{13}$ In turn, columns (5) and (6) revisits the prudential view of high reserves as a response to the vulnerability revealed by recent crisis, by including a systemic banking crisis dummy (crisis), and its first ten lags. While crises do not seem to exert any contemporary influence (indeed, one would expect that reserves go down as result), the cumulative effect of a crisis is positive and significant, either when estimated as the sum of the lags (column 5) or by means of an independent dummy (past_crisis_10) that indicates that the country has suffered a crisis in the preceding ten years (column 6). The same result, stronger, is found when we add banks' foreign assets to the reserve stock. ${ }^{14}$

In sum, there is a strong indication that countries with high FD tend to hold a larger stock of reserves, and tend to adjust it as FD evolves, besides the upward trend associated with recent episodes of global financial turmoil and the country's own history of systemic crises. ${ }^{15}$ This liquidity buffer, while useful as a natural deterrent against liquidity runs, has proved to be inadequate in practice when a bank runs in FD economies finally materializes, leaving open the door for an undue loss of reserves that may ultimately compromise the payment system.

\section{Insurance options}

With all its limitations, self insurance makes perfect sense as the preferred response to the risk of dollar shortages in light of the (lack of) alternative insurance options, namely, external insurance through a contract with private providers of dollar liquidity (typically, a consortium of financial institutions). ${ }^{16}$

Privately provided contingent credit lines (or, more generally, the international outsourcing of the LLR function for small open economies) have been advocated in the

\footnotetext{
${ }^{13}$ Note that the negative correlation with the nominal devaluations is in line with the mercantilist view of reserve accumulation as a buffer against the appreciation of the local currency.

${ }^{14}$ An index of exchange rate regime failed to be significant, contradicting the conventional view that pegs induce further reserve accumulation. Results, omitted here, are available upon request.

15 As I will argue below, the link between FD and reserves can be bi-directional.

16 A third option would be a contract with multilateral financial institutions that may offer the central bank (or individual banks) access to dollar liquidity at a reasonable cost, perhaps the most economically efficient and a constant topic for discussion. The current IMF facilities, contingent and backloaded, are far from being a substitute dollar LLR.
} 
context of the official dollarization debate, ${ }^{17}$ spurring two experiments in Argentina and, partly as a spin-off of the latter, in Mexico. In the first case, the Argentine central bank and a consortium of foreign banks subscribed a contingent credit line in the late 1990s, whereby the central bank-as well as participating local banks_-had the option to enter a repurchase agreement against Argentine sovereign securities. Despite the fact that the coverage of this contract was relatively limited given the size of the Argentine banking sector, its execution was delayed until August 2001, when the bank run has already eroded the existing liquidity buffer and was executed only up to one fourth of the original limit. The second case also included a contingent credit line between Mexico and international banks, which was withdrawn in its entirety by the Mexican government on September 30, 1998, after a decline in oil prices that reduced Mexican fiscal resources combined with a temporary increase in the country's external borrowing costs. However, as to a lesser degree in Argentina, insuring banks were reluctant to disburse the loan and, after releasing the funds, they refused to renew the agreement. ${ }^{18}$

The numbers of the private external insurance contract looked attractive on paper: The Argentine deal, for example, stipulated an annual commitment fee of $32 \mathrm{bps}$ for a contingent line at LIBOR plus 205 basis points, at a time where the spread over the average return on reserves reported by the central bank (a reasonable proxy for the cost of carry of liquidity) was about 570 bps. The result, however, was in both cases rather disappointing.

Was it surprising? Are private partners better positioned to provide LLR services at low cost, as the contract seemed to suggest ex-ante, or are the convenient terms the reflection of mispricing or unreliable commitment? We can shed some light on this issue by means of a simple analytical example.

Assume that, with probability $\pi$, the country faces a systemic liquidity run that leads to an increase in the sovereign spread to the (unsustainably high) $\rho_{H}{ }^{19}$ whereas, with probability $1-\pi$, the country can access international markets at the low sovereign spread $\rho_{L}$. In the absence of liquidity insurance, a liquidity run leads to financial collapse. For the

${ }^{17}$ See Dornbusch and Giavazzi (1998).

${ }^{18}$ See Ize et al. (2005) for a more detailed analysis of these experiences.

${ }^{19}$ Alternatively, we could assume that, beyond certain level of spreads, the country is simply rationed from international markets (market closure). 
purpose of the example, it suffices to assume that the country has strong incentives to avoid this situation, which carries a substantial real costs $K$.

Assuming that the country's obligations maturing during the period are equal to $R$, the authorities have two options to fully insure against the liquidity run (alternatively, against validating unsustainably high roll-over costs):

- Self-insurance: Hold liquid reserves $R$, at a cost of carry $\rho=r-r_{f}$, where $r_{f}$ is the risk-free rate and $\rho$ is the expected sovereign spread $\rho=(1-\pi) \rho_{L}+\pi \rho_{H}$, the risk premium on the country's debt demanded in international markets. In this context, the exante cost of holding reserves is equal to the pre-crisis sovereign spread $\rho$ at the corresponding maturity. ${ }^{20}$

- External (interest rate) insurance: A fair insurance contract with international financial institutions that allows the country to draw down from a credit line up to a given amount $R$ at a predetermined spread $\bar{\rho}$ at a fair (unit) premium $\gamma=c-\pi \bar{\rho}$, where $c$ is the insurer's own cost of carrying liquid assets.

Setting $\bar{\rho}=\rho-\gamma \quad$ (so that the country pays the same under both insurance options), we obtain

$$
\gamma=c-\pi(\rho-\gamma)=\frac{c}{(1-\pi)}-\frac{\pi}{(1-\pi)} \rho
$$

Note that, from the insured country's perspective, the cost of carry of self-insurance in good states is replaced by the fair insurance premium. Thus, the cost of self-insurance exceeds that of external insurance due to the lower carrying cost born by the insurer if, and only if $\rho>c$, since the sole advantage of external insurance relative to self-insurance is precisely the insurer's lower cost of carry. In other words, they would be equally costly unless the intermediation of the insurer reduces the credit risk faced by the investor that ultimately finances either alternative.

The relevant question is, then, under what circumstances and to what extent this is the case in practice? The insurer's cost of carry (the difference between the return from the

\footnotetext{
${ }^{20}$ Note that reserves can take the form of liquid long-term foreign assets (e.g., 10Y US Treasuries), so that no maturity mismatch needs to be incurred.
} 
contract and the opportunity cost of hoarding liquidity) may be below that of the country for two reasons. First, the insurer may enjoy better market access: specifically, it may be able to tap international markets on demand and thus reduce the stock of liquidity that needs to be built up in advance. ${ }^{21}$ Second, the sovereign spread may (and typically does) capture risks not directly associated with the market closure event. Thus, even if the contract increases the exposure of the insurer to the insured country, it does not expose the insurer to all risks affecting sovereign debt (and the country's cost of carry). In particular, an insurance contract aimed at protecting the domestic banking sector from liquidity runs would shield the insurer (at least partially) from debt sustainability problems (whereas the bondholder that helps finance self-insurance will be directly affected by a debt crisis).

The extent to which these factors combined to lower the cost of carry, and whether this justifies external insurance (including the margin charged by the insurer) is difficult to assess. In practice, the two previous experiences with these types of contracts amounted to a rather diluted version of insurance and were subject to serious caveats. Moreover, the low cost of these contracts may have also been reflecting market imperfections that detract from the benefits of external insurance as discussed above.

The first imperfection relates to what could be called inverse moral hazard or, more generally, the inability of the insurer to commit the resources when the option of borrowing is exercised (a weakness that was at play in the Argentine and Mexican experiments). A second imperfection, perhaps the most determinant, is the capacity of the insurer to dilute its exposure at the expense of the co-insurers by shorting the country's assets. ${ }^{22}$

It has been noted before that these two aspects only enhance the advantages of official agencies to provide international LLR coverage: much in the same way as a domestic central bank, an IFI may commit the resources without the need to accumulate reserves ex-ante, and free from the agency problems that undermined the private contract. At any rate, with no official version of the LLR in sight, it is not surprising that governments in FD economies have chosen to self insure.

\footnotetext{
${ }^{21}$ A consortium of insurer banks exposed to the country through the insurance contract may still be able to borrow at reasonable rates while the country thanks to a more diversified asset portfolio, a higher creditworthiness, and even the presence of explicit or implicit guarantees from their home countries. Note that this is essentially the main argument for a centralized LLR in the domestic currency, except that in that case the advantage is rooted in the central bank's capacity to print liquidity on demand.

22 See Broda and Levy Yeyati (2003b).
} 


\section{The problem with self insurance}

Self insurance in its most commonly found form of centralized reserve accumulation may have at least two undesired incentives effects. A stylized example may help illustrate the point.

Consider an economy populated by a continuum of $D$ risk-neutral depositors with one unit of cash savings, where atomistic banks collect short-term deposits at a rate $r_{D}$, and invest them in long-term investments $L$ (loans, for short) with certain returns $r_{D}$ and liquid reserves $R_{B}$ that pay the risk-free rate $r_{f}$. Assume for the moment that banks are always solvent (there is no default risk). Let the size of the systemic deposit run $x$ be distributed according to cumulative distribution function $F(x)$, monotonically increasing and convex over the range $[0,1]$ and, given its systemic nature, independent from bank-specific characteristics. ${ }^{23}$

In the absence of default, a bank facing a liquidity shortage is forced to liquidate its assets at a constant (unit) discount $\theta \cdot{ }^{24}$ At the beginning of the period, the bank chooses the liquidity buffer $R_{B}$ to optimize the tradeoff between the cost of hoarding liquidity and the probability of incurring liquidation costs. For expositional simplicity, all variables are expressed as a share of deposits $D$.

Replacing $L=1-R_{B}$, bank profits (per unit of deposit) in the absence of centralized reserves can be characterized as: ${ }^{25}$

$$
\begin{aligned}
\max _{\left\{R_{B}\right\}} \pi^{e}= & \left(1+r_{L}\right)\left(1-R_{B}\right)+\int_{0}^{R_{B}}\left(1+r_{f}\right)\left(R_{B}-x\right) d F(x) \\
& -\int_{R_{B}}^{1}\left(1+r_{L}\right)(1+\theta)\left(x-R_{B}\right) d F(x)-\int_{0}^{1}\left(1+r_{D}\right)(1-x) d F(x)
\end{aligned}
$$

or, alternatively, as:

\footnotetext{
23 The example focuses on pure liquidity runs and deliberately abstracts from currency mismatches and currency risk; hence, it is independent of the evolution of the exchange rate. Naturally, if —as is often the case - the dollar deposit run is accompanied by a currency run, the resulting real depreciation would only add to the banks' problems via losses on its currency position or -if the dollar deposits are onlent in the same currency- a lower recovery value of dollar loans to non-dollar earners.

${ }^{24}$ Letting the discount increase with $x$ does not alter the implications of this example.

25 In what follows, under the assumption of no default risk, the deposit rate is equal to the risk-free rate $r_{f}$. However, the current notation is kept for expositional purposes.
} 


$$
\max _{\left\{R_{B}\right\}} \pi^{e}=r_{L}-r_{D}-C_{L A R}
$$

where the costs associated with liquidity runs $C$ can be expressed as:

$$
\begin{aligned}
& \left.C=\left(\mid r_{L}-r_{f}\right] F\left(R_{B}\right)-\left[\left(1+r_{L}\right)(1+\theta)-r_{L}\right]\left[1-F\left(R_{B}\right)\right]\right) R_{B} \\
& -\int_{0}^{R_{B}}\left(r_{D}-r_{f}\right) x d F(x)+\int_{R_{B}}^{1}\left[\left(1+r_{L}\right)(1+\theta)-r_{D}\right] x d F(x)
\end{aligned}
$$

and associated first order condition is given by:

$$
-\frac{\partial C}{\partial R_{B}}=-\left(r_{L}-r_{f}\right) F\left(R_{B}\right)+\left(1+r_{L}\right) \theta\left[1-F\left(R_{B}\right)\right]=0
$$

Thus, the optimal liquidity buffer is the one that equals the expected carrying costs (the left-hand side term) to the expected savings in liquidation costs from holding additional reserves (the right-hand side). In turn, the optimal amount of bank reserves $R_{B}$ is given by

$$
R_{B}=F^{-1}\left(\frac{1}{\left[1+\frac{\left(r_{L}-r_{f}\right)}{\left(1+r_{L}\right) \theta}\right]}\right)
$$

from which $\frac{\partial R_{B}}{\partial \theta}>0 ; \frac{\partial R_{B}}{\partial r_{L}}<0 ; \frac{\partial R_{B}}{\partial r_{f}}>0$.

Consider now the influence of centralized reserves. Assume that the central bank assists banks through a liquidity window that commands a penalty rate $r_{L L R}$ such that $1+r_{L}<1+r_{L L R}<\left(1+r_{L}\right)(1+\theta)$ so that the penalty does not exceed the liquidation cost. ${ }^{26}$ Then, if access to the LLR is unlimited, the problem is similar to the previous one with the facility rate substituting the liquidation cost so that the costs of liquidity runs are now:

$$
\begin{aligned}
C_{L L R}= & \left.\left(\mid r_{L}-r_{f}\right\rfloor F\left(R_{B}\right)-\left(r_{L L R}-r_{L}\right)\left[1-F\left(R_{B}\right)\right]\right) R_{B} \\
& -\int_{0}^{R_{B}}\left(r_{D}-r_{f}\right) x d F(x)+\int_{R_{B}}^{1}\left(r_{L L R}-r_{D}\right) x d F(x)
\end{aligned}
$$

from which

$$
-\frac{\partial C_{L L R}}{\partial R_{B}}=-\left(r_{L}-r_{f}\right) F\left(R_{B}\right)+\left(r_{L L R}-r_{L}\right)\left[1-F\left(R_{B}\right)\right]=0 .
$$

or

${ }^{26}$ Note that the latter compounds the liquidation discount and the interest that the bank loses on the liquidated loans. 


$$
R_{B, L L R}=F^{-1}\left(\frac{1}{\left.1+\frac{\left(r_{L}-r_{f}\right)}{\left(r_{L L R}-r_{L}\right)}\right)}\right)<R_{B},
$$

so that cheaper centralized reserves substitute for decentralized reserves.

Under the more general (and realistic) assumption that the facility is limited and that this limit is binding ( $R_{L L R}<\overline{R_{L L R}}<1$ ), the amount available to assist each individual bank would be insufficient in the event of a large enough systemic event, and some liquidation costs should be factored back into the problem:

$$
\begin{aligned}
C_{L L R}= & \left(\left(r_{L}-r_{f}\right) F\left(R_{B}\right)-\left(r_{L L R}-r_{L}\right)\left[F\left(R_{B}+R_{L L R}\right)-F\left(R_{B}\right)\right]-\left[\left(1+r_{L}\right)(1+\theta)-\left(1+r_{L}\right)\right]\left[1-F\left(R_{B}+R_{L L R}\right)\right]\right) R_{B} \\
& -\int_{0}^{R_{B}}\left(r_{D}-r_{f}\right) x d F(x)+\int_{R_{B}}^{R_{B}+R_{L L R}}\left(r_{L L R}-r_{D}\right) x d F(x)+\int_{R_{B}+R_{L L R}}^{1}\left[\left(1+r_{L}\right)(1+\theta)-\left(1+r_{D}\right)\right] x d F(x) \\
& -\left[\left(1+r_{L}\right)(1+\theta)-\left(1+r_{L L R}\right)\right]\left[1-F\left(R_{B}+R_{L L R}\right)\right] R_{L L R}
\end{aligned}
$$

for which the first order condition reads

$$
\begin{aligned}
-\frac{\partial C_{L L R}}{\partial R_{B}}= & -\left(r_{L}-r_{f}\right) F\left(R_{B}\right)+\left(r_{L L R}-r_{L}\right)\left[F\left(R_{B}+R_{L L R}\right)-F\left(R_{B}\right)\right] \\
& +\left(1+r_{L}\right) \theta\left[1-F\left(R_{B}+R_{L L R}\right)\right]=0
\end{aligned}
$$

which tells us, again, that the larger the stock of decentralized reserves $R_{L L R}$ or the lower the interest rate charged by the LLR, the weaker the incentives to hold liquidity at the individual bank level $\left(\frac{\partial R_{B}}{\partial R_{L L R}}<0, \frac{\partial R_{B}}{\partial r_{L L R}}<0\right) \cdot \cdot^{27}$

In this light, what is the optimal (centralized-decentralized) composition of reserves? Intuitively, the answer depends on the carrying costs for each of the players involved. To examine that, we need to be more precise about these costs: It is there that the currency of denomination matters.

When the run is on short-term peso liabilities, the central bank can produce the peso liquidity on demand at a limited cost: Absent solvency concerns, it can borrow directly in the local market at the risk-free rate (or, if needed, finance the assistance through the inflation tax). At any rate, when bank deposits are denominated in pesos, the central bank has a clear advantage because, unlike the commercial banks, it does not need to accumulate reserves in

27Also, as before, $\frac{\partial R_{B}}{\partial \theta}>0 ; \frac{\partial R_{B}}{\partial r_{L}}<0$; and $\frac{\partial R_{B}}{\partial r_{f}}>0$. 
advance. In particular, it can offer centralized reserves at the risk-free rate, bringing the optimal level of decentralized reserves to zero (since $r_{L L R}-r_{f}=0 \Rightarrow \frac{\partial R_{B}}{\partial R_{L L R}}=-1$, so that both sources of insurance are perfect substitutes). In turn, a centralized LLR in pesos entails an efficiency gain for the whole system, as it eliminates the costs associated with hoarding liquidity and (since no resource needs to be invested in liquid assets in advance) enhances the maturity transformation role of the financial sector. ${ }^{28}$

By contrast, when bank liabilities are denominated in dollars, and under the assumption that systemic banking and currency runs coincide cutting the country's access to international markets, dollar liquidity have to be ensured in advance. Therefore, centralized reserves merely substitute for decentralized reserves, and any potential efficiency gains hinges only the relative cost of carry that, in principle, should not differ. ${ }^{29}$ In this case, to the extent that the penalty rate charged to the bank underprice the effective cost to the LLR (alternatively, to the extent that the bank prefers insurance with the central bank than self-insurance), the latter would introduce a subsidy to dollar intermediation that may foster FD beyond the level that banks would choose individually should they have to pay for the required liquidity. However, this is not the only distortion that centralized reserves may introduce, as I show next.

\section{Default risk and moral hazard}

If there is a positive probability of default, limited liability matters. ${ }^{30}$ The simplest way to see this is by assuming that, with probability $1-p$, the investment of the bank goes sour and returns drop to zero. Moral hazard implicitly assumes that the bank has some degree of

\footnotetext{
${ }^{28}$ In a competitive banking sector, liquidity costs would reflect directly in the intermediation spread, and that a LLR at the risk-free rate brings these costs from $C_{L A R}\left(R_{B}^{*}\right)>0$ to $C_{L A R+L L R}=0$. Note that I am deliberately abstracting from diversification gains, as the focus of the paper is on systemic (rather than bank-specific) runs.

${ }^{29}$ In equilibrium, the lending rate should equal the marginal return to capital that, in the absence of financial constraints, in turn determines the government's discount rate (and the marginal borrowing cost it is willing to pay).

${ }^{30}$ The only exception in which the previous results are not altered is under perfect information and no LLR (assuming further that the costs of liquidation of an insolvent bank do not exceed those associated with the fire sale of assets by the bank itself), as the expected return on deposits demanded by depositors (and faced by banks) is independent of the incidence of default. A case along these lines is discussed in Aizenman and Lee (2005).
} 
control over this risk. Here, I simply assume that there is a continuum of investment projects (borrowers) with identical expected returns $\left(p r_{L}\right)=\widetilde{r} \geq r_{f}$, so that $r_{L}(p)=\frac{\widetilde{r}}{p}$. Then, if the probability of a systemic run is uncorrelated with the bank's idiosyncratic credit risk, the bank's problem can be written as:

$$
\max _{R_{B}, p} \pi_{L L R}^{e}=p\left(r_{L}-r_{D}-C_{L L R}\right)
$$

where the first order conditions are

$$
\begin{aligned}
& \frac{\partial \pi_{L L R}^{e}}{\partial R_{B}}=-p \frac{\partial C_{L L R}}{\partial R_{B}}=0 \\
& \frac{\partial \pi_{L L R}^{e}}{\partial p}=r_{L}-r_{D}-C_{L L R}+p\left(1-\frac{\partial C_{L L R}}{\partial r_{L}}\right) \frac{\partial r_{L}}{\partial p}=0 .
\end{aligned}
$$

It follows that

$$
\left.\frac{\partial p}{\partial R_{B}}\right|_{R_{B}=R_{B}^{*}}=-\frac{\frac{\partial^{2} C_{L L R}}{\partial R_{B}^{2}}}{\frac{\partial^{2} C_{L L R}}{\partial R_{B} \partial r_{L}} \times \frac{\partial r_{L}}{\partial p}} \geq 0
$$

since $\frac{\partial r_{L}}{\partial p}<0,-\frac{\partial^{2} C_{L L R}}{\partial R_{B}^{2}} \leq 0$, and

$$
\frac{\partial^{2} C_{L L R}}{\partial R_{B} \partial r_{L}}=F\left(R_{B}+R_{L L R}\right)-\theta\left[1-F\left(R_{B}+R_{L L R}\right)\right]>0 .
$$

Thus, riskier banks choose to hoard a lower level of reserves. The reason is clear: the opportunity cost is higher for a riskier bank that invests in high-return projects (note that both the returns on investment and the costs of hoarding liquidity are relevant only in the event that the bank does not go bankrupt). Moreover,

$$
\frac{\partial^{2} C_{L L R}}{\partial R_{B} \partial R_{L L R}}=\left[\left(1+r_{L}\right) \theta-\left(r_{L L R}-r_{L}\right)\right] F^{\prime}\left(R_{B}+R_{L L R}\right)>0
$$

implies that:

$$
\left.\frac{\partial p}{\partial R_{L L R}}\right|_{R_{B}=R_{B}^{*}}=-\frac{p \frac{\partial^{2} C_{L L R}}{\partial R_{B} \partial R_{L L R}}}{\frac{\partial^{2} C_{L L R}}{\partial R_{B} \partial r_{L}} \times \frac{\partial r_{L}}{\partial p}} \geq 0
$$

which tells us that centralized reserves induce more risk-taking (and, in turn, a lower level of reserves). ${ }^{31}$

${ }^{31}$ Ize et al. (2005) present an alternative illustration of the moral hazard implication of centralized 
In sum, centralized reserves not only partially transfer the cost of the liquidity buffer to the central bank; in addition, it induces more risk-taking overall (relative to the case of no LLR).

\section{Liquid asset requirements (LAR)}

Naturally, there are ways in which the undesired effects of centralized reserve holdings (or a dollar LLR) described above can be addressed, at least in theory. The central bank can (and usually does) restrict its liquidity assistance to limited temporary shortfalls that, if persistent, may lead to intervention and, ultimately, closure. Moreover, the incentive problem can be addressed by conditioning the access to, and cost of the liquidity facility on the degree of risk much in the same way as a risk-based deposit insurance scheme. ${ }^{32}$

However, as the examples of Argentina and Uruguay discussed above illustrate, when left to the discretion of the supervisor, limits and conditions on LLR access in the midst of a systemic run are difficult to enforce. The costs of bank closures (economic contraction, possible domino effects in the banking sector, and even personal costs to the supervisor due to potential litigation) create a serious problem of time inconsistency that, often, results in undue delays or forbearance.

In this context, the most sensible avenue to circumvent the banking sector's free riding on central bank reserves appears to be the requirement of a high liquid asset ratio (LAR) for banks with dollarized liabilities, as most financially dollarized economies have introduced in the late 90 s.

What is the optimal LAR? It is easy to show that, even in the absence of market imperfections, a central planner would not choose the same reserves-to-deposits ratio as the individual bank in the absence of a LLR. Following Aizenman and Lee (2005), assume a Cobb-Douglass technology $y(K)=K^{\alpha}$, where $K$ denotes the stock of capital. A central

reserves, arguing that, in a world with risky and safer types, centralized reserves entail a cross subsidy from the latter to the former. More precisely, they lead risky types to choose a lower $R_{B}$ than safer types, crowding out the use of the LLR assistance, thereby forcing safer banks to hoard an additional amount of reserves. Similarly, in a bi-currency economy with currency risk, it can be shown that a dollar LLR lead banks to incur more risk fostering financial dollarization (Broda and Levy Yeyati, 2003b).

32 See Broda and Levy Yeyati (2003b) for an argument along these lines. 
planner choosing the optimal allocation between investment and the liquidity buffer $R$ in order to optimize returns would solve:

$$
\begin{aligned}
\max _{\{R\}} W_{L L R}^{e}= & \int_{0}^{R}(1-R)^{\alpha} d F(x)+\int_{R}^{1}[1-R-(1+\theta)(x-R)]^{\alpha} d F(x) \\
& +\int_{0}^{R}\left(1+r_{f}\right)(R-x) d F(x)-\int_{0}^{1}\left(1+r_{f}+\rho\right)(1-x) d F(x)
\end{aligned}
$$

from which

$$
\frac{\partial W_{L L R}^{e}}{\partial R}=-\left[\alpha(1-R)^{\alpha-1}-\left(1+r_{f}\right)\right] F(R)+\theta \int_{R}^{1} \alpha[1-R-(1+\theta)(x-R)]^{\alpha-1} d F(x)=0
$$

A simple comparison reveals that the optimal level of reserves for the planner exceeds that for the individual bank. ${ }^{33}$ In addition, in the presence of externalities (e.g., the social costs of a financial collapse, reflected in a larger discount factor $\theta$ ), the planner would prefer a still higher level of coverage. Yet another reason to imposing LAR.

LAR, however, represent a suboptimal self-insurance response to systemic runs. Recall that, in equilibrium,

$$
\pi^{e}\left(R_{B}\right)=0 \Rightarrow r_{L}-r_{D}=\alpha\left(1-R_{B}\right)^{\alpha-1}-r_{f}=C\left(R_{B}\right)>0 .
$$

so that borrowing costs (and, in turn, the cost stock of capital and the level of income) depend negatively on the degree of self insurance -irrespective of whether this level is voluntary or mandatory.

In the limit, they approach a narrow banking structure that makes the banking sector safer at the expense of its financing clout. As such, self-insurance is no panacea: There is, indeed, a tradeoff between insurance and intermediation costs, as liquid reserves detract from the level of productive investment and, at the optimum, still leave room for liquidation losses if the run is deep enough.

\section{Circuit breakers (CBR)}

Can we improve upon this result (that is, reduce $R_{B}$ and increase total output $(1-R)^{\alpha}$

\footnotetext{
33 Note that, under the assumption of a competitive banking sector, in both cases the first term equals the marginal productivity of capital. However, in the second term, the central planner not only considers the liquidation cost but also the positive impact of the reduced stock of capital on the marginal returns to investment in the event of early liquidation (which a price-taking bank do not internalize) increasing the marginal cost of a run.
} 
without raising the exposure to a liquidity run; in other words, reducing the optimal amount of self insurance $R_{B}^{*}$ ) by limiting the convertibility once the run exceeds certain predetermined threshold? Can we use such a limit to deal with large dollar liquidity runs that exceed the optimal amount of liquid reserves? In this section, I argue that can.

In the absence of a liquidity premium, a suspension of convertibility clause that works as a circuit breaker (CBR) for the dollar hemorrhage, is a trivial solution to the problem, since eliminates the need for costly liquidation at no cost. In reality, a CBR would amount to limiting ex-ante the liquidity of deposits (and the maturity transformation role of banks) and would be therefore penalized by a liquidity premium $\rho(\bar{x})$, with $\rho^{\prime}<0, \rho^{\prime \prime}>0$, and $\rho(0)=\rho^{\prime}(0)=0$, on the banks' borrowing costs, where $\bar{x}$ is the parameter that characterizes the CBR policy: the threshold beyond which the run is short-circuited by the CBR. The tradeoff between borrowing costs and liquidation costs is what would determine the optimal LAR-CBR mix.

More formally, under a LAR/CBR policy $\bar{x}>R$, (where $\bar{x}$ is the CBR threshold and $R$ the level of LAR), the central planner's problem can be written as:

$$
\begin{aligned}
\max _{\{x, R\}} W_{L L R}^{e}= & \int_{0}^{R}\left[(1-R)^{\alpha}+\left(1+r_{f}\right) R-\left(1+r_{f}+\rho\right)+\rho x\right] d F(x) \\
& +\int_{R}^{\bar{x}}\left([1-R-(1+\theta)(x-R)]^{\alpha}-\left(1+r_{f}+\rho\right)[1-x]\right) d F(x) \\
& +\int_{x}^{1}\left[[1-R-(1+\theta)(\bar{x}-R)]^{\alpha}-\left(1+r_{f}+\rho\right)(1-\bar{x})\right] d F(x)
\end{aligned}
$$

from which the first order conditions are

$$
\begin{aligned}
\frac{\partial W_{L L R}^{e}}{\partial R}= & {\left[-\alpha(1-R)^{\alpha-1}+\left(1+r_{f}\right)\right] \int_{0}^{R} d F(x) } \\
& +\int_{R}^{\bar{x}}\left(\alpha \theta[1-R-(1+\theta)(x-R)]^{\alpha-1}\right) d F(x) \\
& +\alpha \theta[1-R-(1+\theta)(\bar{x}-R)]^{\alpha-1}[1-F(\bar{x})]
\end{aligned}
$$

and

$$
\begin{aligned}
\frac{\partial W_{L L R}^{e}}{\partial \bar{x}}= & -\left[\alpha(1+\theta)[1-R-(1+\theta)(\bar{x}-R)]^{\alpha-1}-\left(1+r_{f}+\rho\right)\right][1-F(\bar{x})] \\
& -\rho^{\prime}\left[\int_{0}^{\bar{x}}(1-x) d F(x)+(1-\bar{x})[1-F(\bar{x})]\right]=0 .
\end{aligned}
$$

As expected, a tighter CBR avoids liquidation costs at the expense of higher borrowing 
costs. $^{34} \mathrm{~A}$ second thing to note is the fact that LAR and CBR are substitutes (differentiating implicitly, we obtain $\frac{\partial R^{*}}{\partial \bar{x}}>0$ ). Thus, a stricter CBR (a lower threshold $\bar{x}$ ) is associated with a lower optimal level of reserves. The optimal mix between the two will depend on the liquidity premium charged by depositors. ${ }^{35}$

\section{Two banking crises: Argentina and Uruguay}

Two recent systemic banking crises (Argentina 2001, and Uruguay 2002) provide the best illustration of the link between FD and banking fragility, and the limits to crisis management faced by the supervisor in the midst of a crisis - the perfect motivation for the use of a CBR as described above. In both episodes, sudden and devastating runs on dollar deposits crippled banks irrespective of their idiosyncratic fundamentals which, judging from the standard prudential indicators, were a priori in excellent shape. ${ }^{36}$ In both cases, the supervisor intervened belatedly and only after losing most of the (at the time, important) stock of liquid foreign assets, contaminating the payments system. ${ }^{37}$

By late 1999, due to a combination of external factors (the devaluation of the Brazilian real, a strong dollar, and high international interest rates) and internal vulnerabilities (most notably, the presence of substantial private and public dollar liabilities), the Argentine economy was caught in a currency-growth-debt (CGD) trap, whereby the peso was perceived as overvalued, limiting investment and growth, and raising the costs of debt service which in turn induced a reversal of capital flows feed bank into the perceived overvaluation. Still, even by end-2000, judging from standard prudential indicators,

${ }^{34}$ It can be shown that, when $\rho^{\prime}(0)$ is sufficiently high, the solution is interior. Note that a similar tradeoff applies to the analysis of sovereign debt policies (SDRM, CACs) aimed at lowering the incidence of contractionary adjustments in the event of a capital account reversal, at the expense of a liquidity premium that makes up for the limited liquidity of financial claims.

35 An interesting (albeit lateral) aspect of this discussion relates to the fact that this tradeoff entails a sequence of costs: since the CBR eliminates liquidation costs associated with large runs, at the expense of higher borrowing costs in good times, a myopic planner may have a preference for partial self-insurance through LAR.

36 In particular, the average capital-to-asset ratio was approximately 20 percent in Argentina and 14 percent in Uruguay, above the 13 percent in Chile, Peru, and Mexico, and the 11 percent in Colombia. 
Argentina could have been characterized as having a well-capitalized, liquid, and strongly provisioned banking resilient banking sector (in no small part due to the regulatory reform prompted by a previous banking crisis in 1995). ${ }^{38}$

Doubts about the peg to the U.S. dollar built up with the announcement of a plan to peg of the peso to an equally weighted dollar-euro basket (viewed as a disguised devaluation), the resignation of the governor of the central bank (viewed as a guarantor of the peg), and a reform of the central bank charter that blurred the limits on money issuance that underpinned the currency board. As a result, between January 2001 and December 2001, time deposits fell by almost 50 percent (Figure 2). The pattern by currency suggests that deposit dollarization within the system -the depositors' first reaction- turn into a run on dollar deposits as depositors gradually realized that, in a context of dwindling dollar liquidity, a devaluation would inevitably result in bank failures or a forcible currency conversion (Figure 3). By mid-November, with dollar liquidity rapidly running out, the central bank attempted a partial suspension of deposit convertibility with the so-called "corralito" (or little fence), which imposed limits on cash withdrawals out of the banking system, but did not restrict transfers between bank accounts. ${ }^{39}$ Thus, the "corralito" only spread the virus within the banking system, compromising the payments system by failing to isolate stable transactional peso deposits from free-falling dollar saving deposits, and dragging down the real sector by creating a liquidity crush.

Only after civil riots prompted the resignations of two presidents, a sovereign default, the exit of the currency board, a predictable conversion of dollar financial assets into pesos at the below-market 1.4 AR $\$ / U S \$$ exchange rate, and the additional loss of some US $\$ 2$ billion in dollar reserves (all of which happened between December 2001 and late-January 2002) did the government proceed to suspend convertibility of time and (most of) saving deposits in full, by reprogramming them into longer inflation-indexed deposits (the so-called "corralón” or large fence). Ultimately, these new securities were partially exchanged for

${ }^{37}$ For a more detailed account, see Levy Yeyati, De la Torre, and Schmukler (2003) and Levy Yeyati, Martínez Pería and Schmukler (2004) for Argentina, and De Brun and Licandro (2005) for Uruguay.

38 In 1998, right before the recession, the World Bank (1998) ranked Argentina second among 12 emerging economies based on CAMELOT scores (the World Bank's in-house CAMEL rating).

39 The name "corralito" (little fence) was initially adopted because deposits could be used freely inside the financial system but could not leave the system. 
dollar-denominated sovereign bonds in what amounted to tax-financed exchange rate insurance.

The Uruguayan crisis followed a very similar pattern: Uruguay's economy fell into recession in 1999 due to the same set of international factors (plus two idiosyncratic shocks: a severe drought with strong effects on the agricultural sector, and the Argentine recession), public sector finances deteriorated and concerns about the crawling exchange rate band started to increase (which the authorities validated with a forced adjustment of the pre-fixed devaluation rate from 0.6 to 1.2 percent per month in June 2001).

However, there is an important difference with the Argentine episode that helps illustrate the nature of liquidity runs in dollarized economies. Unlike Argentina, Uruguay (helped both by its track record and its advocacy of bank secrecy) has been long considered a regional safe haven. Year 2001 was no exception: despite the recession, total deposits increased by 12 percent, fueled by dollar deposits by non-residents, primarily Argentineans. It was precisely the reversal of this "good" Argentine contagion, however, that triggered the bank run in 2002. Argentineans trapped in the "corralito" started to withdraw from their Uruguayan accounts, initially from the country's two largest private banks, Banco Galicia Uruguay (BGU) and Banco Comercial (both affiliated with Argentine banks). ${ }^{40}$ The overdue intervention of the latter, and the government's apparent lack of dollar liquidity to cope with a sustained run (and honor the implicit 100 percent deposit guarantee under which the system had historically worked) increased the distrust in the Uruguayan banking system and fueled a generalized run. Between January 2002 and July 2002, dollar time deposits in Uruguay fell by about 50 percent (Figure 1). The resulting decline in international reserves led to the abandonment of the crawling band in June $19^{\text {th }}$-and to the resignation of the minister of economy on July $22^{\text {nd }}$. Only on July $30^{\text {th }}$ did the government declare a four-day bank holiday, at the end of which the maturity of dollar time deposits in state-owned (or intervened) banks was extended by Law.

\footnotetext{
${ }^{40}$ Levy Yeyati et al. (2004) reports econometric evidence on the "good" and "bad" contagion from the Argentine crisis.
} 


\section{Final remarks}

The LAR/CBR scheme described above intends to implement in a predictable way the limits that a supervisor typically introduces at a late stage of a crisis once (centralized and decentralized) dollar liquidity is about to run out, in an improvised way that magnify existing uncertainties and pave the way for endless litigation and ultimately fiscally costly settlements. $^{41}$

However, the main advantage of such an explicit scheme is also its main drawback: if correctly publicized, they force to fully internalized the hidden costs of dollar intermediation that are largely socialize during a systemic crisis -which could only result in higher dollar funding costs in non-crisis times.

As usual, there are a number of questions that needs to be answered before a LAR/CBR scheme is put in place in practice. What deposits should be affected by the scheme? When and how should the CBR be activated? How should the level of LAR and the CBR threshold be chosen? How should they be applied selectively in a way that prevents arbitrage between deposit types?

While the preferred combination may depend on a number of case-specific aspects, the previous discussion implicitly suggests a standard prototype of the scheme that may serve as a concrete starting point. First, given that the specific liquidity problem in domestically dollarized economies concerns bank dollar deposits, it is on those deposits that the CBR needs to be applied. However, extending the restriction to dollar demand deposits would be at odds with the objective of preserving the payments system that is built precisely on these transactional accounts. Leaving them CBR-free would, in turn, call for a (substantially) higher LAR on these deposits. ${ }^{42}$

A natural choice would be to set the CBR threshold as a function of the bank's stock of liquid reserves. More precisely, the CBR could be automatically triggered once the LAR on dollar time deposits is exhausted or, more generally, once liquidity falls below the LAR on

${ }^{41}$ CBR resemble the suspension-of-convertibility clause included in bank contracts in Scotland and other European countries during the free banking era (in the eighteen and nineteenth centuries), and in the United States during the national banking period (1863-1914). See Shah (1997), Calomiris and Gorton (1991) for evidence in favor of using some form of CBR.

${ }^{42}$ How close whether the LAR should be close to, or exactly equal to, 100 percent of deposits is debatable. What is important is that the level should be significantly higher than encountered in real life cases. 
dollar demand deposits. On the other hand, even if the CBR is explicitly written in the deposit contract, its recurrent application may create undesired costs for the supervisor, and incentives for banks and depositors to misprice liquidity risk in anticipation of a bailout. Thus, the supervisor may set LAR on dollar time deposits so as to reduce the incidence of the CBR, leaving to the bank the option to hold additional liquidity or to attract new capital in the event of a run, to avoid the reputation cost of resorting to the CBR scheme. In this way, the CBR would protect the backing of transactional deposits, and would be activated automatically while preserving the bank's incentives to seek a less disruptive solution. ${ }^{43}$

While the final toll of the run on the solvency of individual banks will certainly depend on the broader prudential framework and the macroeconomic context in general, a welldesigned LAR/CBR should prevent losses associated with early liquidation and, in the limit, help to avoid avoidable runs altogether.

43 There is an interesting parallel between this scheme and the final approach adopted in Uruguay in 2002: banks that could not meet deposit withdrawals were intervened by the central bank, in which case their deposits were reprogrammed. 


\section{References}

Aizenman, J., and J. Lee (2005), "International reserves: precautionary versus mercantilist views, theory and evidence," IMF working Paper No 05/198.

Armas, Adrián, Alain Ize, and Eduardo Levy Yeyati (forthcoming). Financial Dedollarization: A Policy Agenda, (ed. with), Palmgrave.

Broda, C., and E. Levy Yeyati (2003a), "Dollarization and the Lender of Last Resort," in Dollarization: Debates and Policy Alternatives, ed. by E. Levy Yeyati and F. Sturzenegger (Cambridge, Massachusetts: MIT Press). , (2003b), "Endogenous Deposit Dollarization," Staff Report 160 (New York: Federal Reserve Bank of New York), forthcoming in Journal of Money, Credit and Banking.

Caballero, Ricardo and Arvind Krishnamurthy (2002), "Excessive Dollar Debt: Financial Development and Underinsurance," Journal of Finance, forthcoming. , and S. Panageas (2004), "Contingent Reserves Management: An Applied Framework," NBER Working Paper No. 10786 (Cambridge, Massachusetts: National Bureau of Economic Research).

Calomiris, C., and G. Gorton (1991), "The Origin of Banking Panics: Models, Facts, and Bank Regulation," in Financial Markets and Financial Crisis, ed. by Glenn Hubbard (Chicago: The Chicago University Press), pp. 109-73.

Calvo Guillermo (2005), “Emerging Capital Markets in Turmoil: Bad luck or Bad Policy?”, MIT Press.

Caprio, G., and D. Klingebiel (2004), "Episodes of Systemic and Borderline Financial Crises," World Bank Research Datasets.

Cordella, T., and E. Levy Yeyati (2005a), “Country Insurance,” IMF Staff Papers, 52, pp. 85106, 2005.

Cordella, T., and E. Levy Yeyati (2005b), "A (New) Country Insurance Facility," forthcoming, International Finance.

Cowan, K., E. Levy Yeyati, U. Panizza, and F. Sturzenegger (2006), "Public Debt in the Americas: New Data and Stylized Facts," IDB Working Paper No. . 
De Brun, J., and G. Licandro (2005), "Crisis Management in a Dollarized Economy: The case of Uruguay," forthcoming in Financial Dedollarization: A Policy Agenda, (A. Armas, A. Ize, and E. Levy Yeyati, eds.), Palmgrave.

De Nicoló, Gianni, Patrick Honohan, and Alain Ize (2003), "Dollarization of the Banking System: Good or Bad?," Forthcoming, Journal of Banking and Finance.

Diamond, D., and P. Dybvig (1983), “Bank Runs, Deposit Insurance, and Liquidity,” Journal of Political Economy, Vol. 91, No. 3, pp. 401-19.

Dornbusch, R., and F. Giavazzi (1998), "Hard currency and sound credit: A financial agenda for Central Europe," Available at http://www.mit.edu/ rudi/papers.html.

Eichengreen, B., and R. Hausmann (2005), “Other People’s Money: Debt Denomination and Financial Instability in Emerging-Market Economies," Chicago: The Chicago University Press.

Ize, A., M. Kiguel and E. Levy Yeyati (2005), "Managing Systemic Liquidity Risk in Financially Dollarized Economies," in Financial Dedollarization: A Policy Agenda, (A. Armas, E. Levy Yeyati and A. Ize, eds.), forthcoming, Palmgrave.

Jeanne, O., and R. Ranciere (2005), "The Optimal Level of International Reserves for Emerging Market Countries: Formulas and Applications," mimeo, IMF.

Levy Yeyati, Eduardo (2006), "Financial Dollarization: Evaluating the Consequences," Economic Policy, January 2006.

, María Soledad Martínez Pería and Sergio Schmukler (2004), "Market Discipline under Systemic Risk: Evidence from Bank Runs in Emerging Economies," The World Bank Working Paper No 3440.

, A. De la Torre and S. Schmukler (2003), "Living and Dying with Hard Pegs: The Rise and Fall of Argentina's Currency Board," Economía, vol. 5 (2), pp. 43-99, reprinted in Monetary Unions and Hard Pegs: Effects on Trade, Financial Development, and Stability, Volbert A., J. Mélitz, and G. von Furstenberg, eds., forthcoming, Oxford University Press.

Rajan, Raghuram (2004), "Dollar Shortages and Crises,” NBER Working Paper No. 10845.

Shah, P. (1997), "The Option Clause in Free-Banking, Theory and History: A Reappraisal," Review of Austrian Economics, Vol. 10, No. 2, pp. 1-25.

World Bank (1998), Argentina: Financial Sector Review, Report No. 17864-AR, September. 
Table 1. Deposit dollarization over time

\begin{tabular}{cccccc}
\hline \hline & & Latam & Europe & Asia & $\begin{array}{c}\text { Africa \& } \\
\text { Oceania }\end{array}$ \\
\hline \multirow{2}{*}{1999} & mean & 29.3 & 41.4 & 34.7 & 23.3 \\
& median & 20.9 & 43.7 & 26.5 & 16.9 \\
& Obs. & 24 & 25 & 25 & 25 \\
& min & 0.1 & 1.6 & 2.5 & 0.0 \\
& max & 92.6 & 80.0 & 92.3 & 81.1 \\
\hline \multirow{2}{*}{2004} & mean & 30.8 & 38.4 & 32.8 & 26.0 \\
& median & 27.3 & 38.0 & 29.5 & 20.1 \\
& Obs. & 24 & 25 & 25 & 25 \\
& min & 2.0 & 8.1 & 3.3 & 0 \\
max & 87.6 & 79.9 & 95.7 & 86.0 \\
\hline \hline
\end{tabular}

Source: Levy Yeyati (2006). Balanced Sample. Deposit dollarization is computed as the stock of dollar deposits over total deposits. 
Table 2. Systemic banking crises and deposit dollarization ratios

\begin{tabular}{lcc}
\hline \hline Uganda & 1994 & $17.1 \%$ \\
Armenia & 1994 & $72.2 \%$ \\
Bolivia & 1994 & $78.5 \%$ \\
Jamaica & 1994 & $21.0 \%$ \\
Mexico & 1994 & $7.1 \%$ \\
Guinea-Bissau & 1995 & $50.5 \%$ \\
Zambia & 1995 & $20.1 \%$ \\
Zimbabwe & 1995 & $13.1 \%$ \\
Azerbaijan & 1995 & $49.1 \%$ \\
Bulgaria & 1995 & $29.5 \%$ \\
Latvia & 1995 & $50.4 \%$ \\
Lithuania & 1995 & $40.6 \%$ \\
Russia & 1995 & $28.5 \%$ \\
Argentina & 1995 & $57.1 \%$ \\
Jamaica & 1995 & $18.9 \%$ \\
Paraguay & 1995 & $37.9 \%$ \\
Yemen & 1996 & $41.4 \%$ \\
Croatia & 1996 & $67.6 \%$ \\
Ecuador & 1996 & $22.3 \%$ \\
Indonesia & 1997 & $28.3 \%$ \\
Korea & 1997 & $3.3 \%$ \\
Malaysia & 1997 & $1.8 \%$ \\
Thailand & 1997 & $1.3 \%$ \\
Vietnam & 1997 & $34.1 \%$ \\
Ukraine & 1997 & $25.8 \%$ \\
Philippines & 1998 & $32.6 \%$ \\
Russia & 1998 & $44.0 \%$ \\
Ecuador & 1998 & $36.9 \%$ \\
Turkey & 2000 & $46.8 \%$ \\
Argentina & 2001 & $73.6 \%$ \\
Uruguay & 2002 & $88.4 \%$ \\
\hline \hline & & \\
& & \\
\hline
\end{tabular}

Source: Caprio and Klingebiel (2003). Deposit dollarization is computed as the stock of dollar deposits over total deposits. 
Table 3. Deposit dollarization and reserves: Summary statistics

\begin{tabular}{|c|c|c|c|}
\hline & $\begin{array}{c}\text { CB's reserves } \\
\text { (p-value) } \\
\text { (i) }\end{array}$ & $\begin{array}{c}\text { Comm. banks' } \\
\text { reserves in CB } \\
\text { (p-value) } \\
\text { (ii) }\end{array}$ & $\begin{array}{l}\text { Total reserves } \\
\text { in CB } \\
(p \text {-value }) \\
\text { (iii) }=(\text { i })+(\text { ii) }\end{array}$ \\
\hline mean & 13.6 & 6.3 & 19.8 \\
\hline median & 10.7 & 4.1 & 15.8 \\
\hline Obs. & 1781 & 1781 & 1781 \\
\hline $\min$ & 0 & 0 & 0.5 \\
\hline $\max$ & 133.0 & 94.5 & 183.5 \\
\hline \multicolumn{4}{|c|}{ Correlations } \\
\hline Deposit dollarization & 0.2945 & 0.3316 & 0.3615 \\
\hline \multirow{3}{*}{$\begin{array}{l}\text { Total reserves } \\
\text { in } \mathrm{CB}\end{array}$} & $(0.000)$ & $(0.000)$ & $(0.000)$ \\
\hline & 0.9404 & 0.6497 & \\
\hline & $(0.000)$ & $(0.000)$ & \\
\hline \multirow[t]{2}{*}{$\begin{array}{l}\text { Comm. banks' } \\
\text { reserves in CB }\end{array}$} & 0.3524 & & \\
\hline & $(0.000)$ & & \\
\hline
\end{tabular}

Balanced sample. Dollar deposit and reserves ratios are computed over GDP. 
Table 4. Deposit dollarization and reserves

\begin{tabular}{|c|c|c|c|c|c|c|c|c|c|c|c|c|}
\hline & $(1)$ & $(2)$ & $(3)$ & $(4)$ & $(5)$ & $(6)$ & $(7)$ & $(8)$ & $(9)$ & $(10)$ & $(11)$ & $(12)$ \\
\hline & \multicolumn{2}{|c|}{ CB's reserves } & \multicolumn{2}{|c|}{$\begin{array}{c}\text { Comm. banks' } \\
\text { reserves }\end{array}$} & \multicolumn{2}{|c|}{ Total reserves } & \multicolumn{2}{|c|}{$\begin{array}{c}\text { Comm. banks' } \\
\text { other foreign assets }\end{array}$} & \multicolumn{2}{|c|}{$\begin{array}{c}\text { Comm. banks' } \\
\text { total foreign assets }\end{array}$} & \multicolumn{2}{|c|}{ Total foreign assets } \\
\hline & within & between & within & between & within & between & within & between & within & between & within & between \\
\hline dollar & $\begin{array}{c}\mathbf{0 . 1 7 2 * * *} \\
(0.033)\end{array}$ & $\begin{array}{c}\mathbf{0 . 2 4 1 * *} \\
(0.075)\end{array}$ & $\begin{array}{c}\mathbf{0 . 3 2 6 * * *} \\
(0.055)\end{array}$ & $\begin{array}{c}\text { 0.141*** } \\
(0.038)\end{array}$ & $\begin{array}{c}0.489 * * * \\
(0.063)\end{array}$ & $\begin{array}{c}\mathbf{0 . 3 8 3} * * \\
(0.099)\end{array}$ & $\begin{array}{c}\mathbf{0 . 2 0 3 * *} \\
(0.085)\end{array}$ & $\begin{array}{c}0.312 * * \\
(0.070)\end{array}$ & $\begin{array}{c}\mathbf{0 . 5 1 8} * * * \\
(0.115)\end{array}$ & $\begin{array}{c}\mathbf{0 . 4 5 3} * * \\
(0.089)\end{array}$ & $\begin{array}{c}\mathbf{0 . 6 9 0 * * *} \\
(0.118)\end{array}$ & $\begin{array}{r}\mathbf{0 . 6 9 3} * * \\
(0.135)\end{array}$ \\
\hline year & $\begin{array}{c}\mathbf{0 . 0 0 3} * * * \\
(0.000)\end{array}$ & & $\begin{array}{c}-0.001 * * * \\
(0.000)\end{array}$ & & $\begin{array}{c}\mathbf{0 . 0 0 3} * * * \\
(0.000)\end{array}$ & $\begin{array}{c}-0.010 * * \\
(0.004)\end{array}$ & $\begin{array}{c}\mathbf{0 . 0 0 3} * * * \\
(0.001)\end{array}$ & & $\begin{array}{c}\mathbf{0 . 0 0 3} * * * \\
(0.001)\end{array}$ & & $\begin{array}{c}\mathbf{0 . 0 0 6 * * *} \\
(0.001)\end{array}$ & \\
\hline constant & $\begin{array}{c}-6.658 * * * \\
(0.672)\end{array}$ & $\begin{array}{c}\mathbf{0 . 1 2 0} * * \\
(0.013)\end{array}$ & $\begin{array}{c}1.310 * * * \\
(0.461)\end{array}$ & $\begin{array}{c}\mathbf{0 . 0 4 9} * * \\
(0.006)\end{array}$ & $\begin{array}{c}-5.343 * * * \\
(0.820)\end{array}$ & $\begin{array}{c}19.661 * * \\
(7.997)\end{array}$ & $\begin{array}{c}-5.871 * * * \\
(1.147)\end{array}$ & $\begin{array}{c}\mathbf{0 . 0 7 9} * * \\
(0.012)\end{array}$ & $\begin{array}{c}-4.894 * * * \\
(1.380)\end{array}$ & $\begin{array}{r}\mathbf{0 . 1 2 8 * *} \\
(0.015)\end{array}$ & $\begin{array}{c}-11.421 * * * \\
(1.587)\end{array}$ & $\begin{array}{c}\mathbf{0 . 2 4 8 * *} \\
(0.023)\end{array}$ \\
\hline Observation & 1797 & 1797 & 1822 & 1822 & 1781 & 1781 & 1749 & 1749 & 1730 & 1730 & 1719 & 1719 \\
\hline R-squared & 0.14 & 0.07 & 0.21 & 0.10 & 0.21 & 0.10 & 0.08 & 0.14 & 0.15 & 0.17 & 0.22 & 0.18 \\
\hline Countries & \multicolumn{2}{|c|}{131} & \multicolumn{2}{|c|}{132} & \multicolumn{2}{|c|}{131} & \multicolumn{2}{|c|}{125} & \multicolumn{2}{|c|}{125} & \multicolumn{2}{|c|}{125} \\
\hline
\end{tabular}

Dollar deposit and reserves ratios are computed over GDP. All regressions include country fixed effects.

Robust standard errors in parentheses. *significant at $10 \%$; ** significant at $5 \%$; *** significant at $1 \%$ 
Table 5. High and low deposit dollarization and reserves

\begin{tabular}{|c|c|c|c|c|c|c|c|c|}
\hline & $(1)$ & $(2)$ & (3) & (4) & (5) & (6) & $(7)$ & (8) \\
\hline & \multicolumn{2}{|c|}{ CB's reserves } & \multicolumn{2}{|c|}{ Total reserves } & \multicolumn{2}{|c|}{ Total reserves } & \multicolumn{2}{|c|}{ Total reserves } \\
\hline & Low FD & High FD & Low FD & High FD & Low FD & High FD & Low FD & High FD \\
\hline dollar & $\begin{array}{c}0.112 \\
(0.115)\end{array}$ & $\begin{array}{c}0.174 * * * \\
(0.041)\end{array}$ & $\begin{array}{l}\text { 0.219* } \\
(0.132)\end{array}$ & $\begin{array}{c}\mathbf{0 . 5 3 8} * * * \\
(0.086)\end{array}$ & $\begin{array}{c}\mathbf{0 . 0 4 2} \\
(0.152)\end{array}$ & $\begin{array}{c}0.285 * * * \\
(0.096)\end{array}$ & $\begin{array}{c}\mathbf{0 . 0 7 2} \\
(0.133)\end{array}$ & $\begin{array}{c}0.285 * * * \\
(0.088)\end{array}$ \\
\hline year & $\begin{array}{c}0.002 * * * \\
0.000\end{array}$ & $\begin{array}{c}\mathbf{0 . 0 0 6 * * *} \\
(0.001)\end{array}$ & $\begin{array}{c}0.002 * * * \\
(0.001)\end{array}$ & $\begin{array}{c}\mathbf{0 . 0 0 5} \text { *** } \\
(0.001)\end{array}$ & $\begin{array}{c}\mathbf{0 . 0 0 0} \\
(0.001)\end{array}$ & $\begin{array}{c}\mathbf{0 . 0 0 4} * * * \\
(0.001)\end{array}$ & & \\
\hline m2_gdp & & & & & $\begin{array}{c}\mathbf{0 . 2 1 8} * * * \\
(0.049)\end{array}$ & $\begin{array}{c}0.218 * * * \\
(0.055)\end{array}$ & $\begin{array}{c}\mathbf{0 . 1 8 4} * * * \\
(0.042)\end{array}$ & $\begin{array}{c}\mathbf{0 . 1 8 1} * * * \\
(0.047)\end{array}$ \\
\hline constant & $\begin{array}{c}-4.384 * * * \\
(0.888)\end{array}$ & $\begin{array}{c}-11.412 * * * \\
(1.259)\end{array}$ & $\begin{array}{c}-4.387 * * * \\
(1.033) \\
\end{array}$ & $\begin{array}{c}-9.122 * * * \\
(1.776)\end{array}$ & $\begin{array}{l}-\mathbf{0 . 0 7 0} \\
(1.462) \\
\end{array}$ & $\begin{array}{c}-7.912 * * * \\
(1.816) \\
\end{array}$ & $\begin{array}{l}\mathbf{0 . 0 2 5} \\
(0.027) \\
\end{array}$ & $\begin{array}{l}\mathbf{- 0 . 0 3 9} \\
(0.027) \\
\end{array}$ \\
\hline Observations & 1211 & 586 & 1199 & 582 & 1184 & 578 & 1184 & 578 \\
\hline R-squared & 0.05 & 0.30 & 0.05 & 0.37 & 0.10 & 0.41 & 0.33 & 0.48 \\
\hline Countries & 118 & 130 & 118 & 130 & 115 & 127 & 115 & 127 \\
\hline
\end{tabular}

Dollar deposit and reserves ratios are computed over GDP. All regressions include country fixed effects. Low FD denotes observations for which the deposit dollarization ratio of the preceding year is less than $10 \%$.

Robust standard errors in parentheses.* significant at $10 \%$; ** significant at $5 \%$; *** significant at $1 \%$ 
Table 6. Deposit dollarization and reserves: Robustness

\begin{tabular}{|c|c|c|c|c|c|c|c|c|}
\hline & (1) & (2) & (3) & (4) & (5) & $(6)$ & (7) & (8) \\
\hline & \multicolumn{6}{|c|}{ Total reserves } & \multicolumn{2}{|c|}{ Total foreign assets } \\
\hline & Latam & Non-industrial & & & & & & \\
\hline \multirow[t]{2}{*}{ dollar } & $0.335 * * *$ & $0.294 * * *$ & $0.299 * * *$ & $0.157 * *$ & $0.298 * * *$ & $0.300 * * *$ & $0.270 * *$ & $0.271 * *$ \\
\hline & (0.091) & $(0.067)$ & $(0.067)$ & $(0.070)$ & $(0.063)$ & $(0.063)$ & $(0.125)$ & $(0.124)$ \\
\hline \multirow[t]{2}{*}{ year } & $0.002 * * *$ & 0.000 & 0.000 & 0.000 & $0.003 * * *$ & $0.003 * * *$ & $0.006 * * *$ & $0.005 * * *$ \\
\hline & (0.001) & $(0.000)$ & $(0.000)$ & $(0.001)$ & $(0.001)$ & $(0.001)$ & $(0.001)$ & (0.001) \\
\hline \multirow[t]{2}{*}{$\mathrm{m} 2 \_g d p$} & $0.160 * * *$ & $0.178 * * *$ & $0.189 * * *$ & $0.201 * * *$ & $0.137 * * *$ & $0.135 * * *$ & $0.320 * * *$ & $0.320 * * *$ \\
\hline & $(0.044)$ & $(0.034)$ & $(0.035)$ & $(0.043)$ & $(0.028)$ & $(0.028)$ & $(0.042)$ & $(0.042)$ \\
\hline \multirow[t]{2}{*}{ year } & 0.000 & $0.002 * * *$ & $0.001 *$ & $0.004 * * *$ & $0.003 * * *$ & $0.003 * * *$ & $0.006 * * *$ & $0.005 * * *$ \\
\hline & $(0.000)$ & (0.001) & $(0.001)$ & $(0.000)$ & $(0.001)$ & $(0.001)$ & $(0.001)$ & $(0.001)$ \\
\hline \multirow[t]{2}{*}{ dler } & & & $-0.019 * * *$ & $-0.014 * *$ & & & & \\
\hline & & & $(0.006)$ & $(0.006)$ & & & & \\
\hline \multirow[t]{2}{*}{ ext_debt_gdp } & & & & 0.004 & & & & \\
\hline & & & & $(0.006)$ & & & & \\
\hline \multirow[t]{2}{*}{ crisis } & & & & & -0.010 & -0.009 & 0.008 & 0.008 \\
\hline & & & & & $(0.008)$ & $(0.008)$ & $(0.013)$ & $(0.013)$ \\
\hline \multirow[t]{2}{*}{$\sum_{i=0}^{10}$ crisis_ $i$} & & & & & $0.113 *$ & & $0.273 * * *$ & \\
\hline & & & & & $(0.059)$ & & $(0.077)$ & \\
\hline \multirow[t]{2}{*}{ past_crisis_10 } & & & & & & $0.010 *$ & & $0.025 * * *$ \\
\hline & & & & & & $(0.006)$ & & $(0.008)$ \\
\hline \multirow[t]{2}{*}{ constant } & $-3.649 * * *$ & $-3.298 * * *$ & $-1.845 *$ & $-6.998 * * *$ & $-6.101 * * *$ & $-6.190 * * *$ & $-10.822 * * *$ & $-10.802 * * *$ \\
\hline & (1.393) & (0.991) & (1.009) & (1.063) & $(1.446)$ & $(1.432)$ & $(2.514)$ & (2.492) \\
\hline Observations & 1202 & 1653 & 1751 & 1271 & 1710 & 1710 & 1651 & 1651 \\
\hline R-squared & 0.21 & 0.25 & 0.24 & 0.33 & 0.37 & 0.37 & 0.35 & 0.35 \\
\hline Countries & 98 & 116 & 128 & 100 & 128 & 128 & 122 & 122 \\
\hline
\end{tabular}

Dollar deposit and reserves ratios are computed over GDP. All regressions include country fixed effects.

Robust standard errors in parentheses. *significant at $10 \%$; ** significant at $5 \%$; *** significant at $1 \%$ 
Figure 1. Deposit dollarization around the world

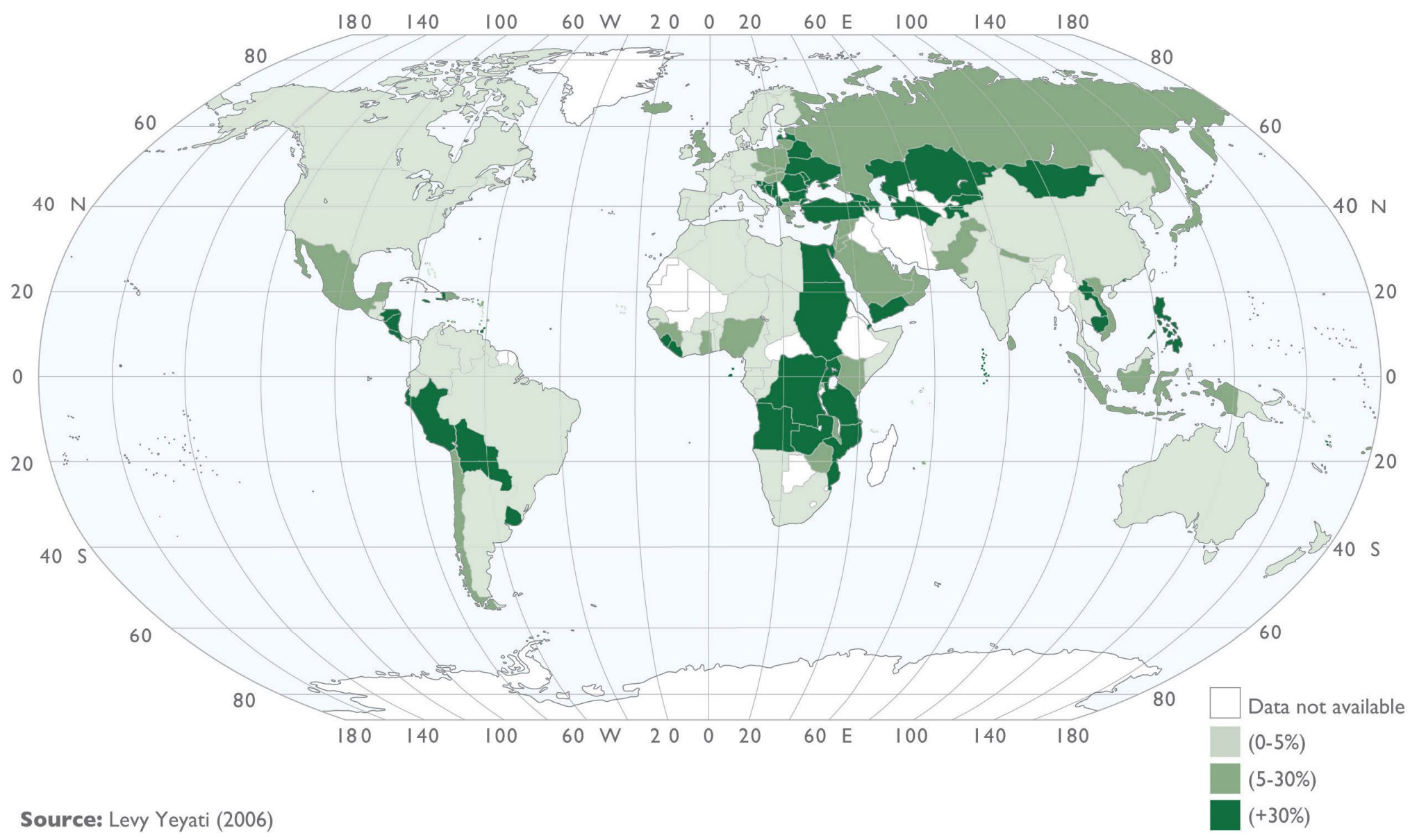


Figure 2. Reserves over time

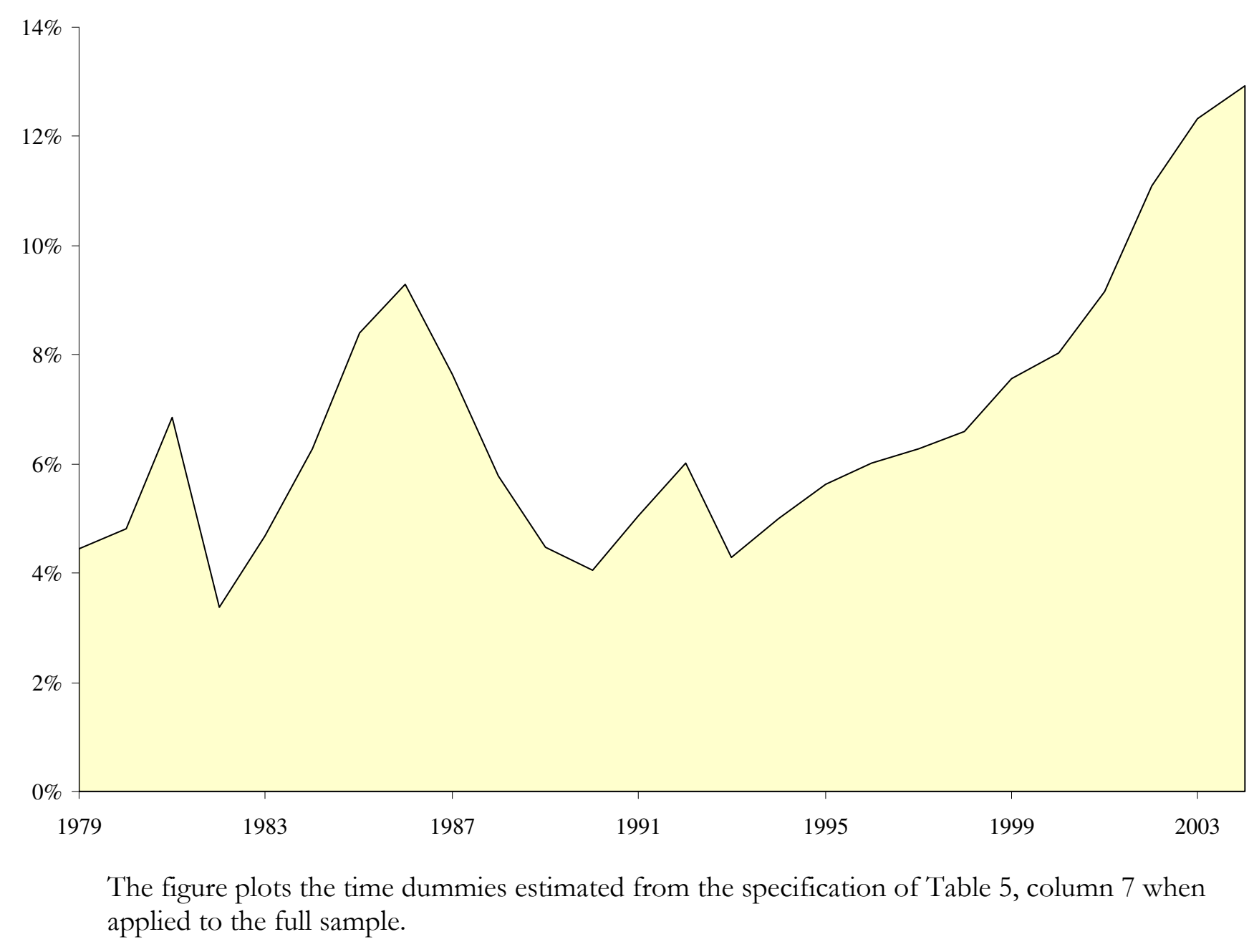


Figure 3. High and low deposit dollarization and reserves: Partial regression plots

Dollar deposits / GDP > 10\%

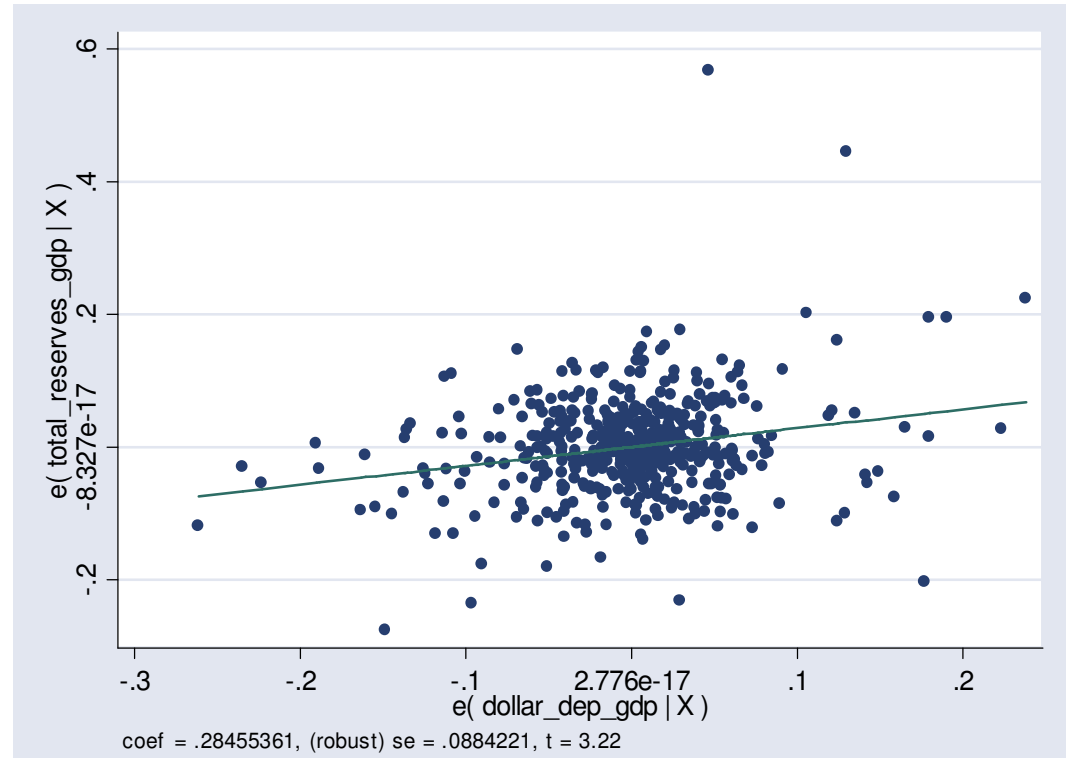

Dollar deposits / GDP $<10 \%$

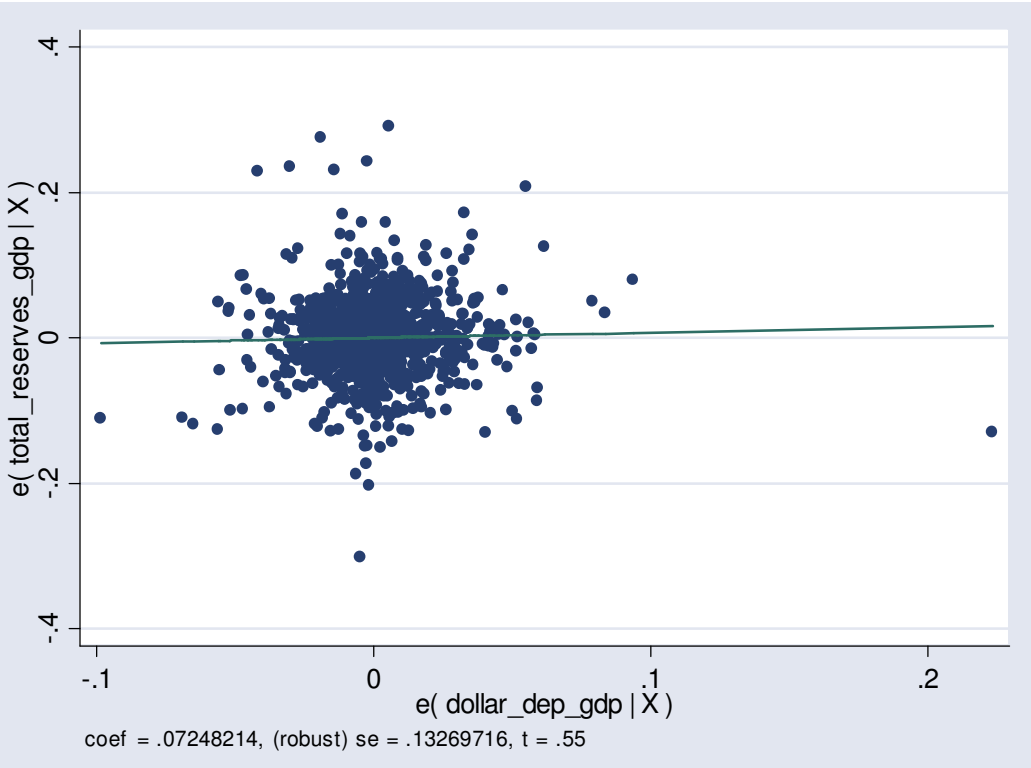




\section{Figure 4. Two banking crises}

\section{Argentina}

(September 2000-December 2001)

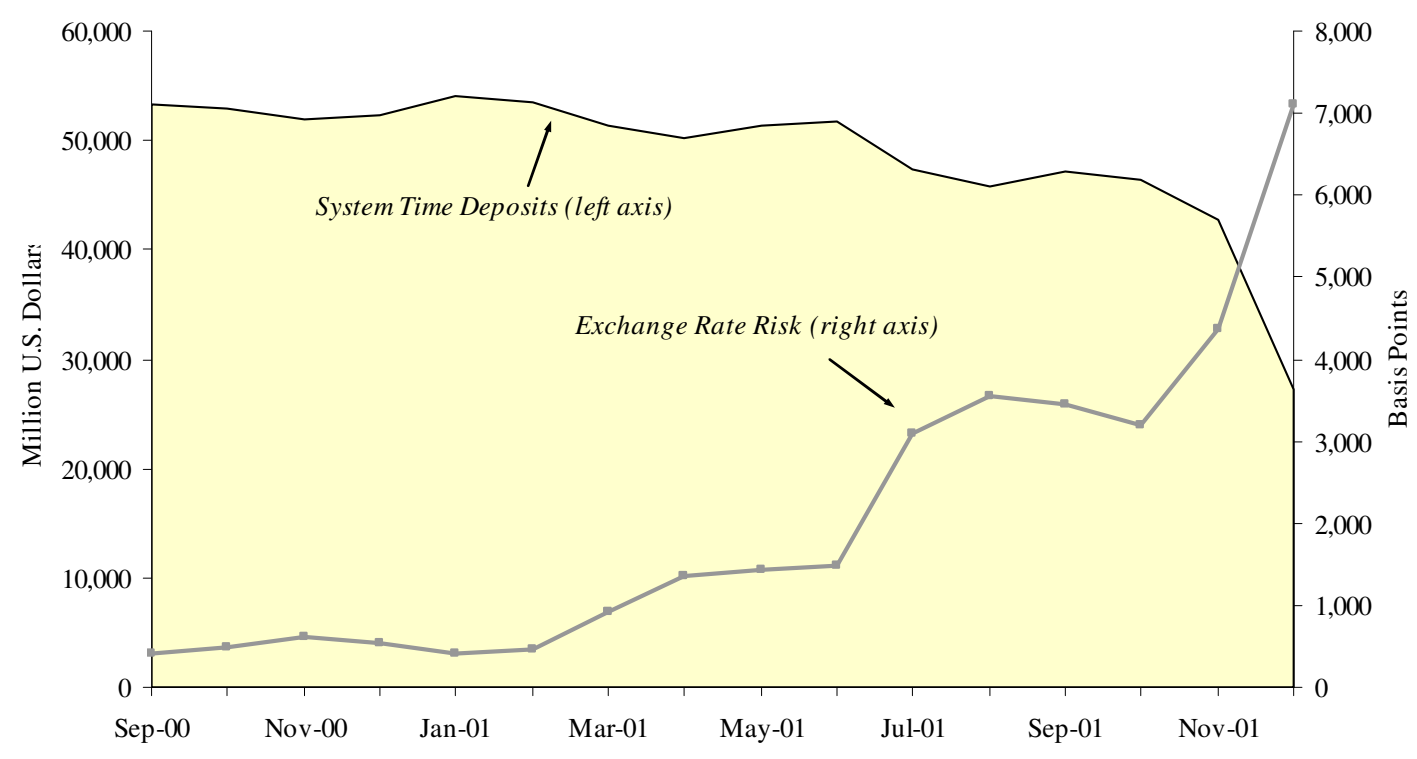

Uruguay

(December 2001-July 2002)

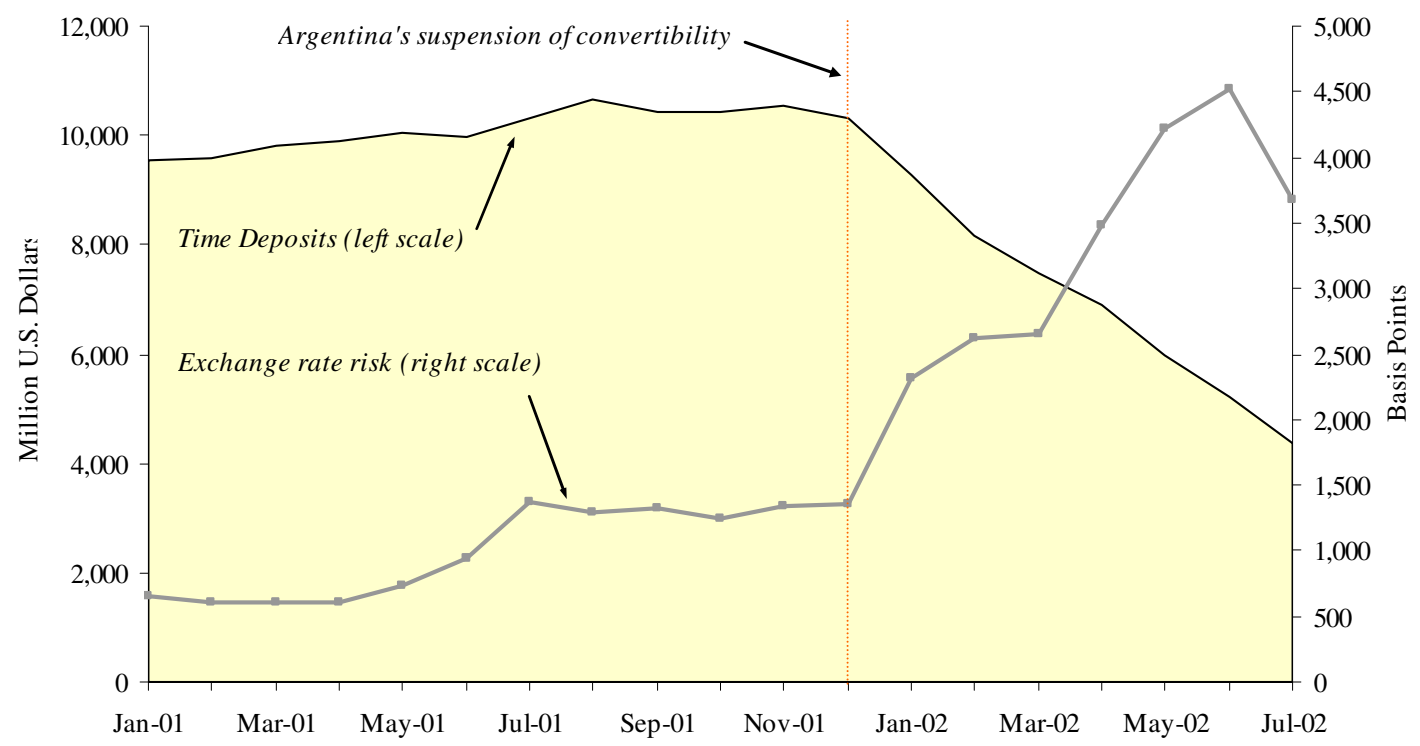

Exchange rate risk is the devaluation implicit in the 12-month forward (NDF) for Argentina, and the (annualized) peso-dollar interest rate differential on time deposits for Uruguay.

Source: Levy Yeyati, Martinez Peria and Schmukler (2005). 
Figure 5. Anatomy of the bank run: Pesos and dollars

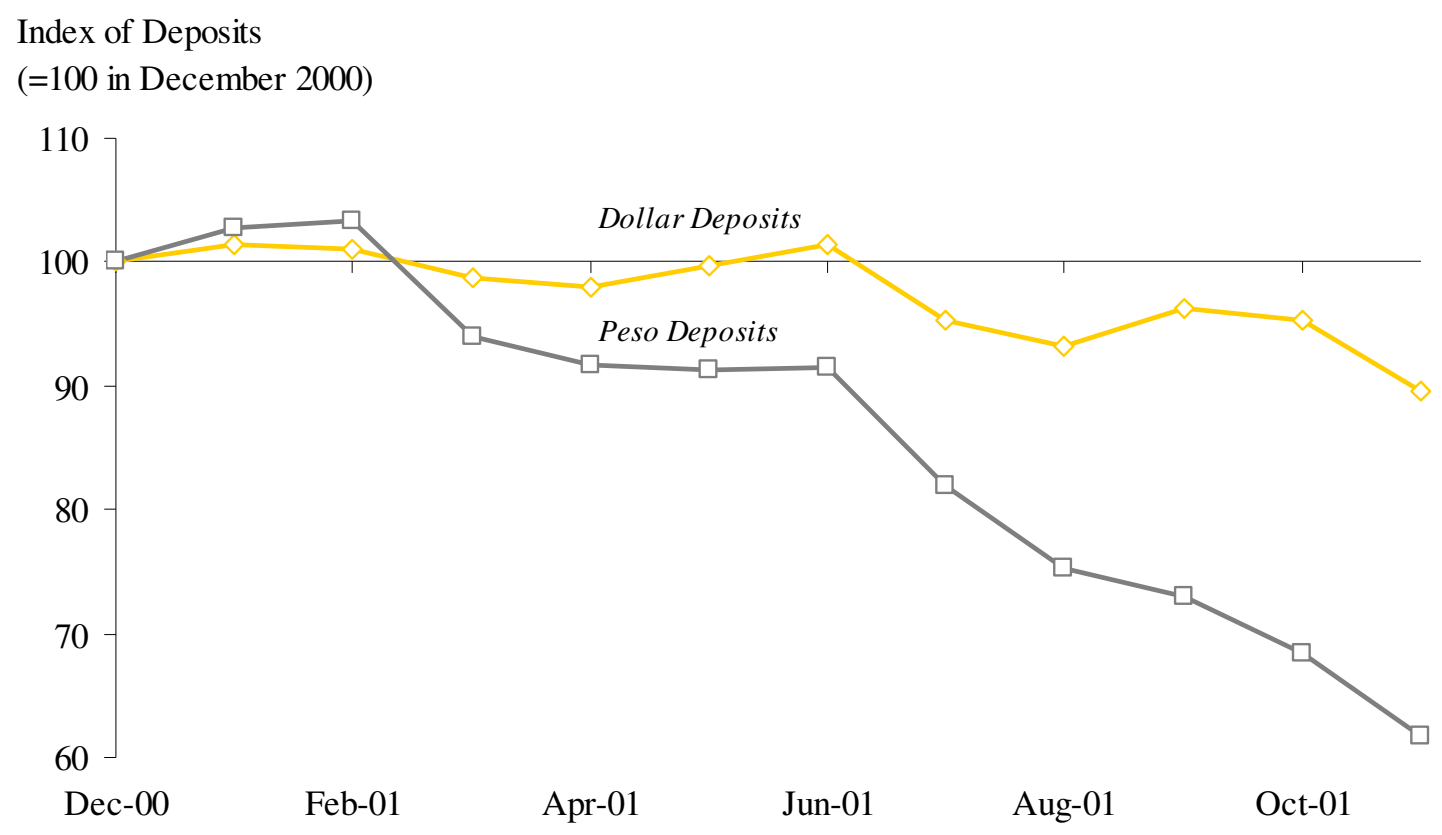

Source: De la Torre, Levy Yeyati and Schmukler (2003). 